\title{
Effect of Sorghum Mulches on Emergence and Seedling Growth of Beggarticks, Goose Grass, and Sesame
}

\author{
Juliet Chengetai Murimwa ${ }^{D},{ }^{1}$ Joyful Tatenda Rugare ${ }^{(D)},{ }^{1}$ Stanford Mabasa ${ }^{(D)}{ }^{1}$ \\ and Ronald Mandumbu $\mathbb{D}^{2}$ \\ ${ }^{1}$ University of Zimbabwe, Faculty of Agriculture Environment and Food Systems, \\ Department of Plant Production Sciences and Technologies, Mount Pleasant, Harare, Zimbabwe \\ ${ }^{2}$ Department of Crop Science, Bindura University of Science Education, Bindura, Zimbabwe \\ Correspondence should be addressed to Joyful Tatenda Rugare; rugarejoy@yahoo.co.uk
}

Received 25 October 2021; Revised 11 February 2022; Accepted 17 February 2022; Published 7 March 2022

Academic Editor: Vijay Gahlaut

Copyright (C) 2022 Juliet Chengetai Murimwa et al. This is an open access article distributed under the Creative Commons Attribution License, which permits unrestricted use, distribution, and reproduction in any medium, provided the original work is properly cited.

\begin{abstract}
Rotation of sorghum (Sorghum bicolor L. Moench) with sesame (Sesamum indicum L.) in drought prone areas of Zimbabwe has raised concerns on whether these two crops are compatible in the rotational system. This is because sorghum is known to exhibit strong allelopathic effects on both crop and weed species. A greenhouse experiment was conducted to assess the effect of soil incorporated sorghum residues on the emergence and seedling growth of sesame and weeds. The emergence and early seedling growth of sesame and the weed significantly $(p<0.05)$ increased with increases in the amount of soil incorporated sorghum residues. Incorporating $27.7 \mathrm{~g}$ of the ground sorghum herbage caused a stimulatory effect on the emergence and early seedling growth of the test species. Liquid chromatography-mass spectrometry revealed the presence of 6 probable allelochemicals in sorghum residues, namely, 4-methylaminobutyrate, C16 sphinganine, oleamide, tauroursdeoxycholic acid, pisatin, and anhalonidine. From this study, it can be concluded that dry sorghum residues do not have an inhibitory effect on sesame emergence and growth at mulch rates that retard emergence and growth of weeds.
\end{abstract}

\section{Introduction}

Sorghum (Sorghum bicolor L. Moench) is an important cereal crop that has been extensively studied for its allelopathic potential and is widely documented as a source of allelochemicals [1]. Allelopathy is defined as the ability of a plant to cause either a suppressive or stimulatory effect on the growth and development of another plant, although this term is loosely used to describe inhibitory effects on the susceptible plant species [2]. Over the years, sorghum has become one of the most studied allelopathic crop, and research work focused on isolating allelochemicals responsible for the suppressive effects [3]. Allelopathic activity of sorghum is particularly attributed to sorgoleone and dhurrin, two important allelochemicals that are produced in the roots and shoots of sorghum, respectively $[4,5]$. Several other allelochemicals with herbicidal activity have been isolated and identified in sorghum, and these include phenolic compounds, coumaric acid, vanillic acid, syringic acid, benzoic acid, gallic acid, caffeic acid, ferulic acid, chlorogenic acid, and protocatechuic acids $[6,7]$.

Methods of exploiting sorghum allelopathy include retention of crop residues as surface mulch, inclusion of sorghum into a crop rotational or intercropping system, and spraying of aqueous extracts (sorgaab) in combination with reduced herbicide dosages $[8,9]$. Previous studies have reported that sorghum exhibited allelopathic activity on the growth and development of both crop and weed species [10]. Wild oat (Avena fatua L.), pigweed (Amaranthus hybridus), fat hen (Chenopodium album L.), nightshade (Solanum nigrum L.), sweet clover (Melilotus parviflora L.), black pigweed (Trianthema portulacastrum L.), field bindweed (Convolvulus arvensis L.), Mexican fire plant (Euphorbia heterophylla L.), and purple nutsedge (Cyperus rotundus L.) 
are some of the weeds whose germination and/or growth is inhibited by sorghum extracts [2, 11-15].

Sesame (Sesamum indicum L.) is an important oil seed crop which is currently being promoted as an alternative to cotton (Gossypium hirsutum L.) in the arid ecological regions of Zimbabwe. This is because of its resilience to harsh conditions created by the adverse effects of climate change and variability. Hussain et al. [16] reported that sesame produces allelochemicals that inhibited growth and development of the purple nutsedge (Cyperus esculentus L.). Other studies reported sesame autotoxicity in crop production systems that promote monoculture of sesame [17]. In anticipation of growing sorghum in rotation with sesame, six registered sesame varieties were screened for tolerance to sorghum allelopathy. The objective of the study was to identify the sesame varieties that are tolerant to allelochemicals released by sorghum mulches at rates that are lethal to weeds of divergent morphology, namely, goose grass (Eleusine indica L. Gaertn) and beggarticks (Bidens pilosa L.). The present study also sought to profile possible allelopathic compounds from dry sorghum leaf and stem herbage using liquid chromatography-mass spectrometry (LC-MS).

\section{Materials and Methods}

2.1. Study Site. The study was carried out in the greenhouse at the University of Zimbabwe (UZ)'s Department of Plant Production Sciences and Technologies in Harare, Zimbabwe, during the 2017/18 summer cropping season. The greenhouse experiment was conducted using natural light and average temperature and humidity and is given in Table 1. LC-MS was done in the Department of Pharmacy at the University of Zimbabwe.

2.2. Sorghum Biomass Preparation. Sorghum variety SC Macia mature plants were harvested dry from SEEDCO's Rattray Arnold Research Station (RARS) in Harare, Zimbabwe $\left(17^{\circ} 14^{\prime} \mathrm{S}, 31^{\circ} 14^{\prime} \mathrm{E}\right)$. RARS is in ecological region II, which is 1314 meters above sea level and receives an annual rainfall of above $750 \mathrm{~mm}$. The stem and leaf portions were separated, chopped into $2 \mathrm{~cm}$ long pieces using secateurs, and dried in the oven at $70^{\circ} \mathrm{C}$ for 48 hours. The different plant parts were ground into powder using a hammer mill grinder. The ground powder was kept in the Weed Science Laboratory at the UZ for three days at room temperature (approximately $23-25^{\circ} \mathrm{C}$ ) before being used in experiments.

2.3. Experimental Design. The greenhouse experiment for sesame was laid out as a $4 * 6$ factorial experiment biomass concentration and sesame variety as the factors. Four levels of sesame biomass concentration that were used in the study are given in Table 2. Six levels of sesame genotype were used, namely, BZ, IETC, Lind 02, LZ, M09, and Z94. The glasshouse experiment was laid out as a completely randomized design (CRD) with four treatments replicated six times. On the other hand, beggarticks and goose grass weed bioassays were laid out separately as CRD with four treatments replicated six times.

2.4. Experimental Procedure. Pots measuring $20 \mathrm{~cm}$ diameter and $18 \mathrm{~cm}$ height were three-quarter filled with oven sterilized sandy soil (clay $4 \%$, silt $13 \%$, and sand $83 \%$ ). Sorghum ground residues were added to the pots and thoroughly mixed with the top $5 \mathrm{~cm}$ of the soil [18]. Stems and leaves were not separated because they were equally effective in the laboratory bioassay [19] and also to try to mimic field conditions where above ground tissues are retained as mulch. The treatments used in the study are given in Table 2. Ten sesame seeds or 25 weed seeds were shallowly planted in the respective pots in which the soil was mixed with different sorghum herbage, as given in Table 2 . Thereafter, the pots were watered daily with $450 \mathrm{ml}$ of water. The experiment was terminated 28 days after sowing of seeds of either sesame or weeds.

2.5. Nutritional Composition of Dry Sorghum Residues. Quantification of nitrogen in dry residues of sorghum variety SC Macia was carried out in the UZ's Food Nutrition Department using the Kjeldahl method described by [20]. In addition, quantification of phosphorus and potassium was done using UV-Vis and flame atomic absorption spectroscopy, respectively. The sample for the phosphorus and potassium analyses was prepared using the method described by Lozano-Calero et al. [21]. Nutritional composition of the sorghum dry residues is given in Table 3 .

2.6. Liquid Chromatography-Mass Spectrometric (LC-MS) Analysis of Allelopathic Compounds in Sorghum Residues. To isolate possible allelopathic compounds in sorghum variety SC Macia herbage, $200 \mathrm{~g}$ of mixed leaf and stem powder was mixed with $1000 \mathrm{ml}$ of $70 \%$ HPLC grade methanol. The mixture was shaken on an orbital shaker at $150 \mathrm{rpm}$ for twelve hours at room temperature. Subsequently, the mixture was filtered using four layers of cheesecloth, and the filtrate was centrifuged at $4000 \mathrm{rpm}$ for 15 minutes using a centrifuge (Model Dynac II Centrifuge, Clay Adams). Methanol in the resultant solution was removed at $80^{\circ} \mathrm{C}$ using a rotary evaporator (rotary evaporator, Biobase). To remove water from the aqueous solution remaining, beakers containing solution from the rotary evaporator were suspended in a waterbath set at a temperature of $80^{\circ} \mathrm{C}$ until all water had evaporated. Identification of possible allelopathic compounds in the crude sorghum extract was done using a Model Agilent Technologies' 6530 Accurate-Mass Q-TOF LC/MS [22].

2.7. Data Analysis. Data collected in the experiments were subjected to analysis of variance (ANOVA) using GenStat version 14. Data were tested for normality using the Shapiro-Wilk test. Mean separation was done using Fisher's protected least significance difference (LSD) at 5\% significance level. 
TABLE 1: Average temperature and humidity in the greenhouse.

\begin{tabular}{lccccc}
\hline $\begin{array}{l}\text { Average temperature } \\
\left({ }^{\circ} \mathrm{C}\right)\end{array}$ & $\begin{array}{c}\text { Average max temperature } \\
\left({ }^{\circ} \mathrm{C}\right)\end{array}$ & $\begin{array}{c}\text { Average min temperature } \\
\left({ }^{\circ} \mathrm{C}\right)\end{array}$ & $\begin{array}{c}\text { Average humidity } \\
(\%)\end{array}$ & $\begin{array}{l}\text { Average max } \\
\text { humidity }(\%)\end{array}$ & $\begin{array}{c}\text { Average min } \\
\text { humidity }(\%)\end{array}$ \\
\hline 29.5 & 35.9 & 16.4 & 52.9 & 97.3 & 29.8 \\
\hline
\end{tabular}

TABLE 2: Treatments used in the soil incorporated biomass greenhouse experiment.

\begin{tabular}{lc}
\hline Treatments & Concentration of sorghum whole plant biomass added to the soil in the pots \\
\hline Treatment 1 & Control (no biomass added) \\
Treatment 2 & $10.5 \mathrm{~g}$ ground sorghum biomass \\
Treatment 3 & $18.4 \mathrm{~g}$ ground sorghum biomass \\
Treatment 4 & $27.7 \mathrm{~g}$ ground sorghum biomass \\
\hline
\end{tabular}

TABle 3: Macronutrient composition of the dry sorghum residues used in the study.

\begin{tabular}{|c|c|c|c|c|c|}
\hline Nutrient & $\begin{array}{c}\text { Amount of nutrient in } \\
2 \mathrm{~g} \text { ground sorghum } \\
\text { sample }\end{array}$ & $\begin{array}{c}\text { Amount of nutrient in } \\
10.5 \mathrm{~g} \text { sorghum } \\
\text { biomass } / 19.4 \mathrm{~m}^{2}\end{array}$ & $\begin{array}{c}\text { Amount of nutrient in } \\
18.4 \mathrm{~g} \text { sorghum } \\
\text { biomass } / 19.4 \mathrm{~m}^{2}\end{array}$ & $\begin{array}{c}\text { Amount of nutrient in } \\
27.7 \mathrm{~g} \text { sorghum } \\
\text { biomass } / 19.4 \mathrm{~m}^{2}\end{array}$ & $\begin{array}{l}\text { Recommended nutrient } \\
\text { amount } / 19.4 \mathrm{~m}^{2} \text { [2] }\end{array}$ \\
\hline Nitrogen & 0.238 & 1.249 & 2.189 & 3.296 & 0.02716 \\
\hline Phosphorus & 0.264 & 1.387 & 2.431 & 3.659 & 0.0543 \\
\hline Potassium & 0.131 & 0.686 & 1.202 & 1.809 & 0.0272 \\
\hline
\end{tabular}

\section{Results}

3.1. Effect of Different Soil Incorporated Sorghum Residues on Sesame. The interaction between sesame variety and biomass concentration on the final emergence, dry shoot weight, and dry root weight of sesame was not significant $(p>0.05)$. There were significant $(p<0.05)$ differences among the sesame varieties on the final emergence percentage (Table 4). Final emergence of sesame was significantly lower in IETC compared to the other sesame varieties (Table 4). On the other hand, the final emergence percentage of Lindi Zimbabwe was significantly higher than Brown Zimbabwe, Ziada 94, and Lindi 02 but was statistically similar to Mtwara 09. Incorporation of sorghum ground biomass did not affect dry shoot and dry root weight of all the varieties used in the study (Table 4).

3.2. Effect of Sorghum Soil Incorporated Biomass on Beggarticks. The effect of soil incorporated sorghum biomass amount was significant $(p<0.05)$ on final emergence of beggarticks, but not on dry shoot $(p>0.05)$ and dry root weight (Figure 1). Beggarticks final emergence percentage increased with increasing concentration of soil incorporated sorghum residues (Figure 1(a)). There were no significant differences between the other treatments except $27.7 \mathrm{~g} \mathrm{pot}^{-1}$, which resulted in significantly higher final emergence than the other treatments. Conversely, the different concentrations of sorghum soil incorporated biomass did not significantly $(p>0.05)$ affect dry root and shoot weight of beggarticks (Figures 1(b) and 1(c)).

3.3. Effect of Sorghum Soil Incorporated Biomass on Goose Grass Emergence and Growth. The effect of soil incorporated sorghum biomass concentration was significant $(p<0.05)$ on final emergence, dry shoot, and root weight of goose grass (Figure 2). All the parameters measured increased as the sorghum ground biomass concentration increased from $0 \mathrm{~g}$ to $10.5 \mathrm{~g} \mathrm{pot}^{-1}$; emergence, dry shoot weight, and dry root weight also increased from $0 \mathrm{~g}$ to $10.5 \mathrm{~g} \mathrm{pot}^{-1}$. However, a further increase in sorghum ground biomass concentration from 10.5 to $18.4 \mathrm{~g} \mathrm{pot}^{-1}$ did not significantly $(p>0.05)$ affect seedling emergence and growth.

3.4. Liquid Chromatography-Mass Spectrometric Analysis of Allelopathic Compounds in Sorghum Whole Plant Dry Residues. LC-MS analysis of extracts of sorghum variety SC Macia showed major molecular peaks at different $m / z$ values of the possible allelopathic phenolic compounds (Figure 3). At a retention time range of 22.913-23.354 minutes, phenolic compounds 4-methylaminobutyrate (Figure 1(a)), C16 sphinganine (Figure 3(b)), and anhalonidine (Figure 3(c)) were detected (Table 5). Tauroursdeoxycholic acid (Figure 4(a)), pisatin (Figure 4(b)), and oleamide (Figure $4(\mathrm{c})$ ) were detected at a retention time range of 0.160-0.364 minutes (Table 5).

\section{Discussion}

The ground residues of sorghum were not effective at suppressing sesame, beggarticks, and goose grass seedling emergence and dry weight under greenhouse conditions. Increasing the amount of sorghum residues stimulated emergence and early seedling growth of all the test species. The highest final emergence percentage and early seedling growth were observed at maximal amount of sorghum biomass incorporated into the soil. These results contradict the findings by Ayeni and Kayode [14] who reported that increasing the amount of ground sorghum residues from $0 \mathrm{~g}$ to $50 \mathrm{~g}$ in $5600 \mathrm{~g}$ of soil reduced Euphorbia heterophylla 
TABLE 4: Effect of soil incorporated sorghum biomass on the final emergence, shoot dry weight, and root dry weight of six sesame varieties.

\begin{tabular}{|c|c|c|c|}
\hline Sesame variety & Emergence (\%) & Dry shoot weight (g) & Dry shoot weight $(\mathrm{g})$ \\
\hline \multicolumn{4}{|c|}{ Sesame varietal effect } \\
\hline IETC & $18.3^{\mathrm{a}}$ & 0.798 & 0.211 \\
\hline Brown Zimbabwe & $39.6^{\mathrm{b}}$ & 1.205 & 0.298 \\
\hline Ziada 94 & $40.0^{\mathrm{b}}$ & 1.221 & 0.241 \\
\hline Lindi 02 & $35.0^{\mathrm{b}}$ & 0.946 & 0.259 \\
\hline Mtwara 09 & $46.2^{\mathrm{bc}}$ & 1.165 & 0.411 \\
\hline Lindi Zimbabwe & $56.7^{\mathrm{c}}$ & 1.444 & 0.220 \\
\hline$P$ value & $<0.001$ & 0.063 & 0.340 \\
\hline LSD & 14.15 & ns & ns \\
\hline $\mathrm{CV} \%$ & 63.0 & $73.7 \%$ & $126.8 \%$ \\
\hline \multicolumn{4}{|c|}{ Sorghum residue level effects } \\
\hline Biomass amount & Emergence (\%) & Dry shoot weight $(\mathrm{g})$ & Dry root weight $(\mathrm{g})$ \\
\hline 0 (control) & $26.9^{\mathrm{a}}$ & $0.649^{\mathrm{a}}$ & $0.133^{\mathrm{a}}$ \\
\hline 10.5 & $38.6^{\mathrm{b}}$ & $1.205^{\mathrm{b}}$ & $0.298^{\mathrm{ab}}$ \\
\hline 18.4 & $38.6^{\mathrm{b}}$ & $1.221^{\mathrm{b}}$ & $0.199^{\mathrm{bc}}$ \\
\hline 27.7 & $53.1^{\mathrm{c}}$ & $1.634^{\mathrm{c}}$ & $0.434^{\mathrm{c}}$ \\
\hline$P$ value & $<0.001$ & $<0.001$ & 0.002 \\
\hline LSD & 11.55 & 0.4047 & 0.1571 \\
\hline $\mathrm{CV} \%$ & 63.0 & 73.7 & 126.8 \\
\hline
\end{tabular}

Means followed by the same letter in the column are not significantly different at $p<0.05$.

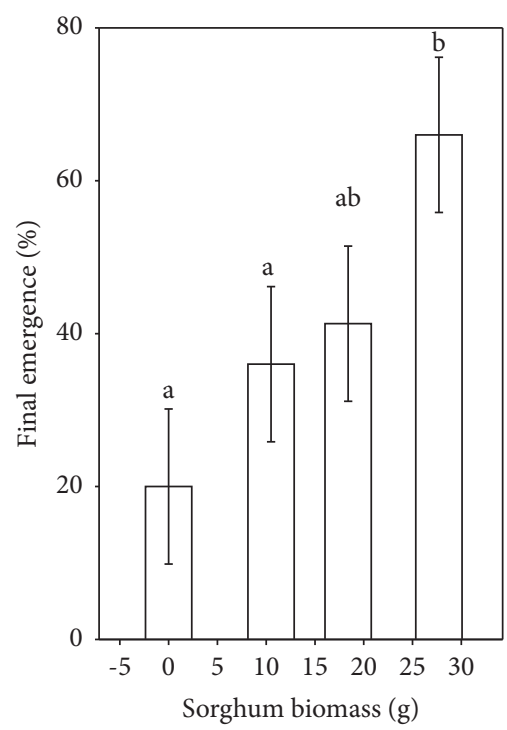

(a)

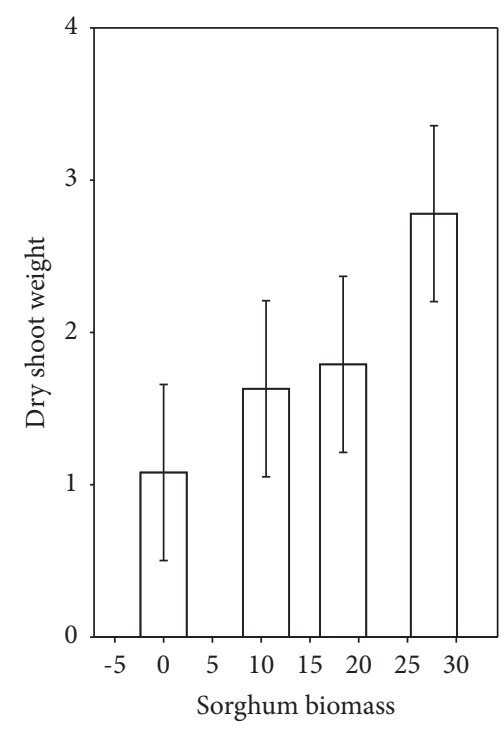

(b)

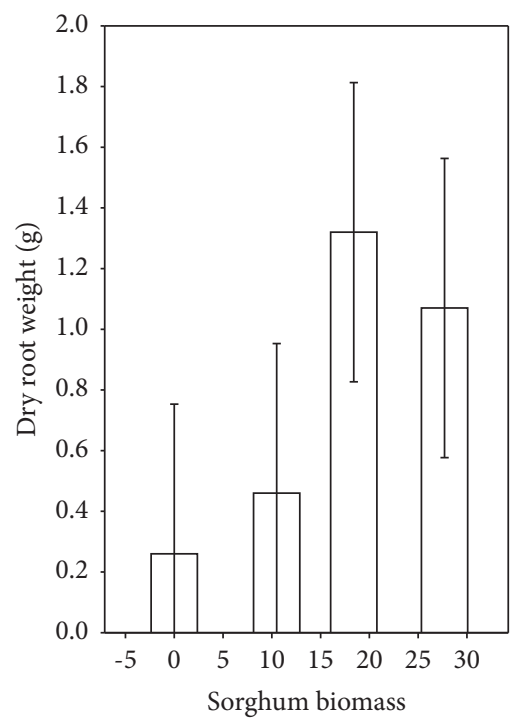

(c)

FIGURE 1: Effect of ground sorghum biomass on the final emergence (a), shoot dry weight (b), and root dry weight (c) of beggarticks. Bars indicated with different letters show that there were significant $(p<0.05)$ differences between treatments. Error bars represent LSD at $p<0.05$.

L. germination percentage, dry shoot, and dry root weight. Kandhro et al. [15] reported that ground sorghum herbage suppressed broadleaved weeds, Trianthema portulacastrum L., Digera arvensis L., and Convolvulus arvensis L., but not beggarticks. These results imply that farmers cannot rely on sorghum mulches to control weeds in sesame because of the stimulatory effect they have on the crop and weeds. During the first three to four weeks, sesame seedlings are a poor competitor with more vigorous weeds, and if the weeds and crop emerge simultaneously, weeds affect sesame seedling establishment [19].
The findings from this study suggest that sorghum allelopathy is influenced by several factors, and in this case, lack of allelopathic activity in the greenhouse experiment could be a result of several factors including soil type, presence of microorganisms in the soil, or high levels of nitrogen $(\mathrm{N})$, phosphorus $(\mathrm{P})$, and potassium $(\mathrm{K})$ in sorghum ground residues. In this study, NPK levels supplied to the germinating and developing sesame, beggarticks, and goose grass seeds increased as the amount of ground sorghum residues increased. The NPK levels provided by sorghum residues (Table 3 ) exceeded the required amounts 


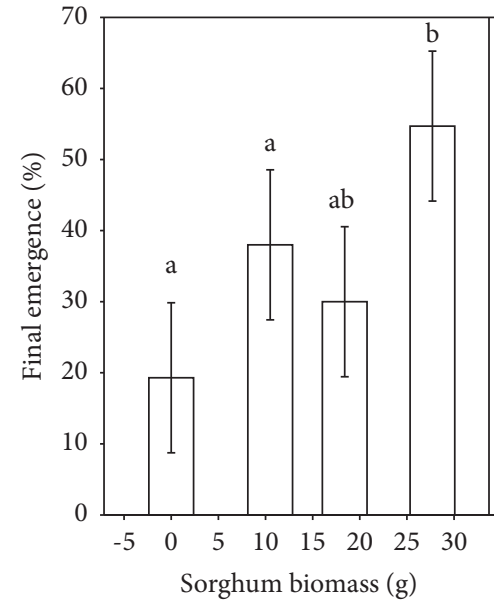

(a)

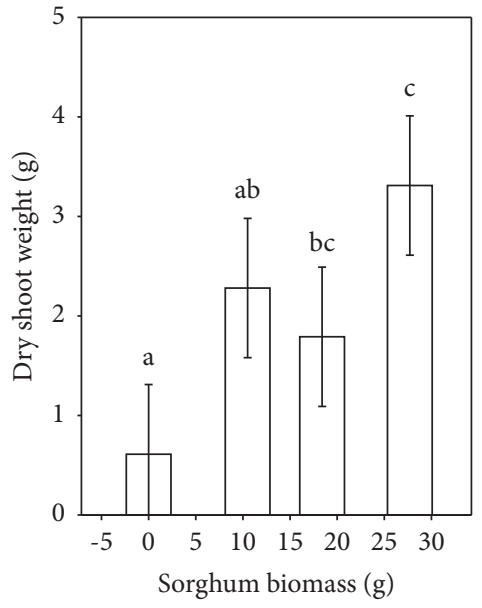

(b)

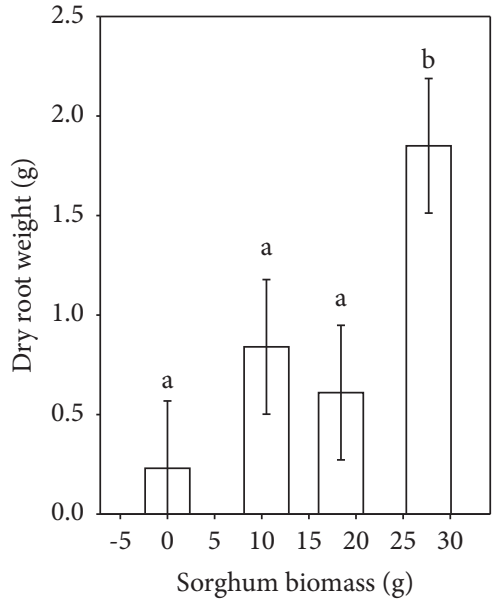

(c)

FiguRE 2: Effect of ground sorghum biomass on (a) the final emergence, (b) shoot dry weight, and (c) root dry weight (c) of goose grass. Bars indicated with different letters show that there was a significant $(p<0.05)$ differences between treatments. Error bars represent LSD at $p<0.05$.

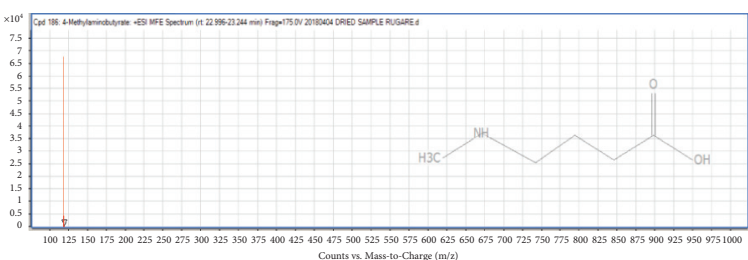

(a)

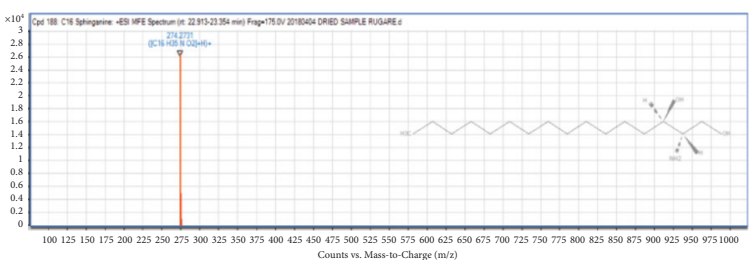

(b)

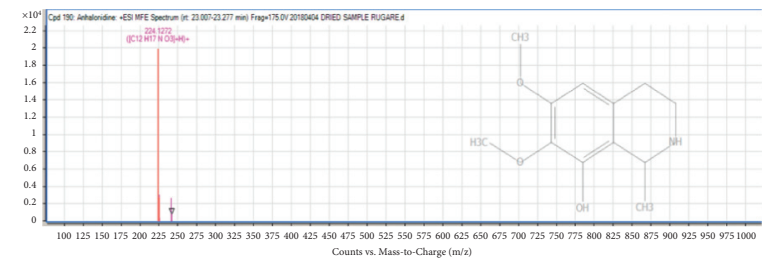

(c)

FIGURE 3: Cumulative LC-MS spectra for (a) 4-methylaminobutyrate, (b) C16 sphinganine, and (c) oleamide that were detected in sorghum variety SC Macia extracts.

TABle 5: Retention times, mass spectra data, and tentative identification of the phenolic compounds in sorghum variety SC Macia.

\begin{tabular}{|c|c|c|c|c|c|c|}
\hline Proposed compound & Chemical formula & Rt (min) & Exact mass & Calculated mass & Volume (\%) & Score \\
\hline 4-Methylaminobutyrate & $\mathrm{C}_{5} \mathrm{H}_{11} \mathrm{NO}_{2}$ & 23.093 & 117.0785 & 117.1565 & 1.15 & 98.30 \\
\hline C16 sphinganine & $\mathrm{C}_{16} \mathrm{H}_{35} \mathrm{NO}_{2}$ & 23.131 & 273.2659 & 273.5009 & 0.89 & 96.19 \\
\hline Oleamide & $\mathrm{C}_{18} \mathrm{H}_{35} \mathrm{NO}$ & 0.216 & 281.2716 & 281.4529 & 0.60 & 85.42 \\
\hline Tauroursdeoxycholic acid & $\mathrm{C}_{26} \mathrm{H}_{45} \mathrm{NO}_{6} \mathrm{~S}$ & 0.279 & 499.2973 & 499.854 & 0.40 & 84.91 \\
\hline Pisatin & $\mathrm{C}_{17} \mathrm{H}_{14} \mathrm{O}_{6}$ & 0.263 & 314.079 & 314.2504 & 0.15 & 82.83 \\
\hline Anhalonidine & $\mathrm{C}_{12} \mathrm{H}_{17} \mathrm{NO}_{3}$ & 23.145 & 223.1199 & 223.2764 & 0.38 & 82.55 \\
\hline
\end{tabular}

reported by Mudani [23]. This suggests that high amounts of nutrients in ground sorghum herbage could have masked the detrimental effects of allelopathy. The lack of phytotoxic activity could be attributed to the presence of high amounts of nitrogen, phosphorus, and potassium in larger amounts which consequently allowed the sesame and weeds to grow luxuriously. The high levels of nitrogen provided to sesame, beggarticks, and goose grass in this study may have assisted in breaking seed dormancy and a concomitant increase in seed germination and seedling emergence. It is also possible that the high levels of phosphorus contained in the sorghum residues could have stimulated root development, thereby 


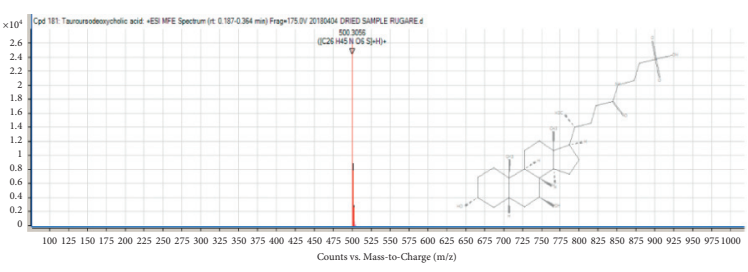

(a)

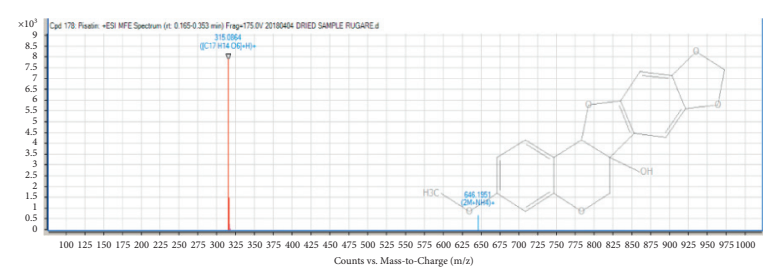

(b)

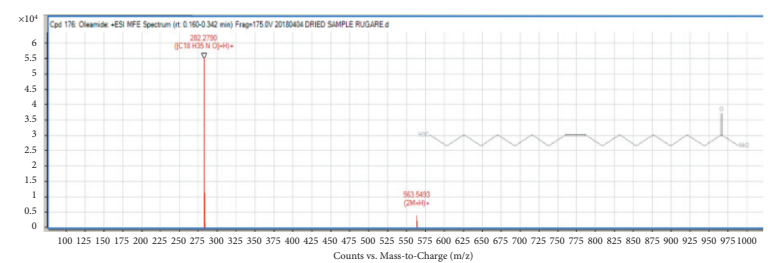

(c)

Figure 4: Cumulative LC-MS spectra for (a) tauroursdeoxycholic acid, (b) pisatin, and (c) anhalonidine that were detected in sorghum variety SC Macia extracts.

promoting faster seedling development resulting in increased growth of seedlings. It is also possible that the germination, emergence, and growth stimulation that was observed could be due to toxicant-induced hormesis. Recent allelopathy studies have attributed an increase in seedling growth when allelochemicals are applied at dosages lethal to weeds but stimulatory to crops to hormesis $[24,25]$. The results of this study encourage retention of sorghum residues as surface mulches not soil-incorporated residues to suppress weeds in sesame by creating a microclimate that discourages germination and growth of photoblastic weed seeds. Similar recommendations were given by Muslim AlEqaili et al. [26] who reported that wheat (Triticum aestivum L.) residues as surface mulches were effective at controlling weeds, whilst wheat residue incorporation into the soil was not effective in managing weeds. The use of sorghum residues or aqueous extracts for weed control may not effectively control weeds when used alone. Therefore, sorghum allelopathy should be a component of an integrated weed control strategy. The lack of phytotoxic damage on sesame when planted in soils mixed with sorghum residues suggests the possibility of rotating sorghum with sesame without the fear of crop damage due to sorghum allelopathy.

The possible allelopathic compounds in sorghum variety SC Macia above ground parts were identified as 4-methylaminobutyrate, C16 sphinganine, anhalonidine, tauroursdeoxycholic acid, pisatin, and oleamide. These compounds were isolated and identified at a retention time range of $0-25$ minutes. Most of the phenolic compounds were obtained at a retention time range of $0-1$ minute as shown by a major peak during this period. The compound 4methylaminobutyrate with $\mathrm{m} / z 117$ and 23.093 retention time had the highest volume, but its presence in sorghum is not yet documented. Pisatin which was eluted at $\mathrm{m} / \mathrm{z} 314$ and retention time 0.263 minutes has been identified as the defence molecule against pathogen attack in several plants including tomato (Solanum esculentum L.) and peas (Pisum sativum L.) [27].
All the compounds that were obtained in this study have not yet been reported in sorghum as possible allelochemicals. This could be because most research focus has been on sorgoleone and dhurrin as the major allelochemicals in sorghum, and identification of specific phenolics or flavonoids is still yet to be done [28]. It is also because previous research studies were carried out using live sorghum plant material which contains high levels of sorgoleone and dhurrin. Since in conservation agriculture (CA) most farmers use dry material, we considered it appropriate to use dry sorghum material in order to mimic the situation that is under smallholder conditions.

\section{Conclusion}

From this study, it can be concluded that soil incorporated dry sorghum residues does not have inhibitory effects on the germination and emergence of sesame and the weeds. Liquid chromatography-mass spectrometry revealed the presence of six probable allelochemicals in sorghum residues, namely, 4-methylaminobutyrate, C16 sphinganine, oleamide, tauroursdeoxycholic acid, pisatin, and anhalonidine.

\section{Data Availability}

The data used to support the findings of this study are available from the corresponding author upon request.

\section{Conflicts of Interest}

The authors declare that they have no conflicts of interest.

\section{Acknowledgments}

The authors thank the German Academic Exchange Service for funding this research work and to SEEDCO for providing the sorghum material used in the experiments. 


\section{References}

[1] A. Moosavi, R. T. Afshari, A. Asadi, and M. H. Gharineh, "Allelopathic effects of aqueous extract of leaf stem and root of sorghum bicolor on seed germination and seedling growth of Vigna radiata L," Notulae Scientia Biologicae, vol. 3, no. 2, pp. 114-118, 2011.

[2] K. Mubeen, M. A. Nadeem, A. Tanveer, and Z. A. Zahir, "Allelopathic effects of sorghum and sunflower water extracts on germination and seedling growth of rice (Oryza sativa L.) and three weed species," Journal of Animal and Plant Science, vol. 22, pp. 738-746, 2012.

[3] Z. A. Cheema, A. Khaliq, and S. Saeed, "Weed control in maize (Zea mays L.) through sorghum allelopathy," Journal of Sustainable Agriculture, vol. 23, no. 4, pp. 73-86, 2004.

[4] S. R. Baerson, F. E. Dayan, A. M. Rimando et al., "A functional genomics investigation of allelochemical biosynthesis in Sorghum bicolor root hairs," Journal of Biological Chemistry, vol. 283, no. 6, pp. 3231-3247, 2008.

[5] Z. A. Cheema, A. Khaliq, and M. Farooq, "Sorghum allelopathy for weed management in wheat," in Allelopathy in Sustainable Agriculture and Forestry, R. S. Zeng, A. U. Mallik, and S. M. Luo, Eds., pp. 255-270, Springer New York, New York, NY, USA, 2008.

[6] A. R. M. Al-Tawaha and N. Odat, "Use of sorghum and maize allelopathic properties to inhibit germination and growth of wild barley (Hordeum spontaneum)," Not Bote Horti Agrobot Cluj-Napoca, vol. 38, pp. 124-127, 2010.

[7] L. C. D. A. Barbosa, M. L. Ferreira, A. J. Demuner, A. A. d. Silva, and R. d. C. Pereira, "Preparation and phytotoxicity of sorgoleone analogues," Química Nova, vol. 24, no. 6, pp. 751-755, 2001.

[8] L. A. Weston, I. S. Alsaadawi, and S. R. Baerson, "Sorghum allelopathy-from ecosystem to molecule," Journal of Chemical Ecology, vol. 39, no. 2, pp. 142-153, 2013.

[9] K. Jabran, "Sorghum allelopathy for weed control," in $M a-$ nipulation of Allelopathic Crops for Weed Control, Springer Briefs in Plant ScienceSpringer International Publishing, Berlin, Germany, 2017.

[10] I. S. Alsaadawi and F. E. Dayan, "Potentials and prospects of sorghum allelopathy in agroecosystems," Allelopathy Journal, vol. 24, pp. 255-270, 2009.

[11] Z. A. Cheema, A. Khaliq, and H. M. I. Sadiq, "Efficacy of sorgaab (sorghum water extract) as a natural weed inhibitor in wheat," International Journal of Agriculture Biology, vol. 2, pp. 144-146, 2000.

[12] M. A. Czarnota, R. N. Paul, F. E. Dayan, C. I. Nimbal, and L. A. Weston, "Mode of action, localization of production, chemical nature, and activity of sorgoleone: a potent psii inhibitor in sorghum spp. root exudates1," Weed Technology, vol. 15, no. 4, pp. 813-825, 2001.

[13] M. R. Uddin, K. W. Park, Y. K. Kim, S. U. Park, and J. Y. Pyon, "Enhancing sorgoleone levels in grain sorghum root exudates," Journal of Chemical Ecology, vol. 36, no. 8, pp. 914-922, 2010.

[14] M. J. Ayeni and J. Kayode, "Allelopathic effects of aqueous extracts from residues of Sorghum bicolor stem and maize inflorescence on the germination and growth of Euphorbia heterophylla L," Journal of Plant Studies, vol. 2, pp. 1-6, 2013.

[15] M. N. Kandhro, S. D. Tunio, I. Rajpar, Q. D. Chachar, and A. W. Gandahi, "Allelopathic impact of sorghum and sunflower on germination and seedling growth of summer broadleaf weeds," Pakistan Journal of Agriculture Engineering Veterinary Science, vol. 31, pp. 229-239, 2015.
[16] I. Hussain, N. B. Singh, A. Singh, and H. Singh, "Allelopathic potential of sesame plant leachate against Cyperus rotundus L," Annals of Agrarian Science, vol. 15, no. 1, pp. 141-147, 2017.

[17] F. J. Lyu, Z. H. Zhang, R. Q. Wang et al., "Response of sesame root exudates at different growing stages to continuous cropping and its autotoxicity," Chinese Journal of Oil Crop Sciences, vol. 43, no. 6, pp. 1087-1098, 2021.

[18] M. Runzika, J. T. Rugare, and S. Mabasa, "Screening green manure cover crops for their allelopathic effects on some important weeds found in Zimbabwe," Asian Journal of Agriculture Rural Development, vol. 3, pp. 554-565, 2013.

[19] J. C. Murimwa, J. T. Rugare, S. Mabasa, and R. Mandumbu, "Allelopathic effects of aqueous extracts of sorghum (Sorghum bicolor L. Moench) on the early seedling growth of sesame (Sesamum indicum L.) varieties and selected weeds," International Journal of Agronomy, 2019.

[20] N. J. Thiex, H. Manson, S. Anderson, and J. Å. Persson, "Determination of crude protein in animal feed, forage, grain, and oilseeds by using block digestion with a copper catalyst and steam distillation into boric acid: collaborative study," Journal of AOAC International, vol. 85, no. 2, pp. 309-317, 2002.

[21] D. Lozano-Calero, P. Martìn-Palomeque, and S. MadueñoLoriguillo, "Determination of phosphorus in cola drinks," Journal of Chemical Education, vol. 73, no. 12, pp. 1173-1174, 1996.

[22] J. T. Rugare, P. J. Pieterse, and S. Mabasa, "Effects of green manure cover crops (Canavalia ensiformis L. and Mucuna pruriens L.) on seed germination and seedling growth of maize and Eleusine indica L. and Bidens pilosa L. weeds," Allelopathy Journal, vol. 50, no. 1, pp. 121-140, 2020.

[23] S. Mudani, "Identification of desirable sesame (Sesamum indicum L.) varieties and appropriate plant spacing and inorganic fertilizer requirements," MSc thesis, University of Zimbabwe, Harare, Zimbabwe, 2016.

[24] R. G. Belz, K. Hurle, and S. O. Duke, "Dose response-a challenge for allelopathy?" Nonlinearity Biology Toxicology Medicine, vol. 3, pp. 173-211, 2005.

[25] M. A. Iqbal, "Role of Moringa, Brassica and Sorghum water extracts in increasing crops growth and yield: a review," American-Eurasian Journal of Agriculture \& Envrionmental Science, vol. 14, pp. 1150-1158, 2014.

[26] S. A. N. Muslim Al-Eqaili, N. R. Lahmod, and O. H. Eshkandi, "Weed management in sesame field (Sesamum indicum L) using wheat straw and tillage or no tillage systems," American Journal of Agricultural and Biological Sciences, vol. 12, no. 2, pp. 100-103, 2017.

[27] AJ. Kettle, Degradation of the benzoxazolinone class of phytoalexins by Fusarium pseudograminerum, a pathogen fungus of wheat, PhD Thesis, University of Queensland, Brisbane, Australia, 2016.

[28] R. Ashraf, B. Sultana, S. Yaqoob, and M. Iqbal, "Allelochemicals and crop management: a review," Current Science, vol. 3, pp. 1-13, 2017. 